DR MARYLINE MOULIN (Orcid ID : 0000-0002-5685-2451)

Article type : Paper

\title{
Title of manuscript: Gondwana breakup: messages from the North Natal Valley
}

\author{
M. Moulin ${ }^{*}$, D. Aslanian'1, M. Evain ${ }^{1}$, A. Leprêtre ${ }^{1,2}$, P. Schnurle ${ }^{1}$, F. Verrier ${ }^{1}$, J. Thompson ${ }^{1}$, P. \\ De Clarens ${ }^{3}$, S. Leroy ${ }^{4}$, N. Dias ${ }^{5,6}$ and the PAMELA-MOZ35 Team ${ }^{1,2,3,4,5,6,7,8,9,10,11,12,13}$
}

${ }^{1}$ Ifremer, REM/GM/LGS, Centre de Brest, 29280 Plouzané, France,mmoulin@ifremer.fr

${ }^{2}$ LGO, Laboratoire Geosciences Ocean, IUEM, CNRS, 29280 Plouzané, France

${ }^{3}$ Total, R\&D, avenue Larribau, 64000 Pau, France

${ }^{4}$ UPMC, Univ Paris 6, CNRS UMR 7193, ISTEP, 4 place Jussieu, 75005 Paris, France

5 ISEL - Instituto Superior de Engenharia de Lisboa, Lisboa, Portugal

${ }^{6}$ IDL - Instituto Dom Luis, Lisboa, Faculdade das Ciências da Universidade de Lisboa, 1749-016 Lisboa, Portugal

${ }^{7}$ AWI, Am Alten Hafen 26, D-27568 Bremerhaven, Germany

8 BGR, Geozentrum Hannover, Stilleweg 2, 30655 Hannover, Germany

${ }^{9}$ INAMI, Praça 25 de Junho, n’380, P.O. Box. 217, Maputo, Mozambique

10 IFPEN, 1 \& 4, avenue de Bois-Préau, 92852 Rueil-Malmaison Cedex, France

${ }^{11}$ INP - Instituto Nacional de Petróleo, Rua dos Desportistas, Parcela $n^{\circ} 259$ E, Maputo, Mozambique

12 Nelson Mandela Metropolitan University, Port Elisabeth, South Africa

This article has been accepted for publication and undergone full peer review but has not been through the copyediting, typesetting, pagination and proofreading process, which may lead to differences between this version and the Version of Record. Please cite this article as doi: $\underline{10.1111 / \text { TER. } 12448}$

This article is protected by copyright. All rights reserved 
${ }^{13}$ IMAF, Instituto Nacional do Mar e Fronteiras, Av. Ahmed Sekou Touré nr, 21, 6o Andar, Flat 61, C.P. 4189, Maputo, Mozambique

\section{ABSTRACT}

The Natal Valley, offshore Mozambique, is a key area for understanding the evolution of East Gondwana. Within the scope of the integrated multidisciplinary PAMELA project, we present new wide-angle seismic data and interpretations, which considerably alter Geoscience paradigms. These data reveal the presence of a $30 \mathrm{~km}$-thick crust that we argue to be of continental nature. This falsifies all the most recent paleo-reconstructions of the Gondwana. This $30 \mathrm{~km}$-thick continental crust $1000 \mathrm{~m}$ below sea level implies a complex history with probable intrusions of mantle-derived melts in the lower crust, connected to several occurrences of magmatism, which seems to evidence the crucial role of the lower continental crust in passive margin genesis.

\section{INTRODUCTION}

Since Aslanian et al., 2009 and Kumar et al., 2009, very few works on passive margin formation modeling have analyzed the implications of inherent horizontal movement in terms of kinematic reconstruction and intraplate deformation (for instance: Blaich et al., 2011; Brune et al., 2017; Kukla et al., 2018). Notwithstanding, to understand the genesis and evolution of continental passive margins we need to define their current and initial geometries, their crustal segmentation and its nature by combining high quality multi-channel (MCS) and wide-angle seismic data. We also need to determine the exact conjugate margin system and its tightest initial position and constrain horizontal and vertical motions (subsidence) by studying the overlying sedimentary sequences with a focus on paleoenvironments and stratigraphic sequences (for instance Leroux et al., 2015).

Therefore, all propositions, interpretations and conceptual models must be restored on precise paleogeographic maps to test their consequences on the global view and be validated or falsified (Aslanian \& Moulin, 2012). Symmetrically, paleo-geographic reconstructions should take into account all observations available on passive margins and continental deformation to avoid gaps and overlaps (Moulin et al., 2010; Thompson et al., 2019).

The disintegration of Pangea occurred on two parallel breakups, spaced $6000 \mathrm{~km}$ apart, in the Central Atlantic Ocean and the Indian Ocean (Figure 1A). Whilst the opening of the Central Atlantic Ocean is 
now well dated at Sinemurian (195 Ma) (Sahabi et al., 2004), the age of the Indian Ocean and the initial position of the different plates (Madagascar, India and Antarctica) with respect to Africa are still under debate (Sahabi, 1993; Leinweber and Jokat, 2012; Gaina et al., 2013; Gibbons et al., 2013; Gaina et al., 2015; Reeves et al., 2015; Nguyen et al., 2016; Davis et al., 2016; Mueller \& Jokat, 2019; Thompson et al., 2019) (Figure 1B). The Northern Natal Valley (NNV) holds a key position in the East Gondwana breakup. Whilst the Southern Natal Valley (SNV), separated from the NNV, by the Naude Ridge (NR), since Goodlad et al., (1982) and Martin et al., (1981), is commonly interpreted as an oceanic crust with Mesozoic magnetic anomalies (M12 to M0), the NNV is subject to controversy as the magnetic anomalies are very weak and the seismic images very poor: old wideangle seismic data (Ludwig et al., 1968) were interpreted as imaging either continental crust (Dingle and Scrutton, 1974; Lafourcade, 1984) or oceanic crust (Ludwig et al., 1968). Green (1972) interpreted the northern Mozambique ridge as a N/S spreading centre, and Marks and Tikku (2001) proposed the recognition of magnetic anomalies from chron M11 to chron M2 as an evidence of an extinct E-W spreading center in the middle of the NNV. This debate leads to two tendencies for the Gondwana reconstruction (Figure 1C): an old hypothesis with a loose fit in the Mozambique area (Sahabi, 1993) and a set of recent models with a tighter fit implying a large overlap of plates. For instance, Mueller and Jokat, (2019), derived from the Leinweber and Jokat model (2012) proposed a $300 \mathrm{~km}$-wide overlap of the Antarctic plate on the Mozambican Coastal Plain (MCP) and the NNV, implying an oceanic nature of substratum for both areas. However, new results based on both inversion and forward analysis of new sea surface vector geomagnetic data acquired in 2009 (Hanyu et al., 2017) seem to rule out the existence of an extinct E-W spreading center and support instead the presence of stretched continental crust, with basaltic magma intrusion in the NNV. The MCP, East of the Lebombo monocline, exhibits low crustal velocities, from 1-D shear wave velocity profiles (Domingues et al., 2016) inconsistent with the presence of an oceanic crust as suggested by most of the recent models of Gondwana reconstruction (Figure 1B). Finally, the new kinematic fit proposed by Thompson et al., (2019) supports the same conclusions.

\section{METHODS}

This article is protected by copyright. All rights reserved 
During the PAMELA-MOZ3-5 cruise (2016) (Moulin \& Aslanian, 2016; Moulin \& Evain, 2016) on the R/V Pourquoi Pas?, new marine geophysical and geological data were acquired (bathymetry, coring, water column, sub-bottom profiler, gravity, magnetism, dredges, wide-angle and reflection seismic) with the aim of resolving this controversy. We conducted 193 deployments of Ocean Bottom Seismometers from the Ifremer pool (Auffret et al., 2004) over seven profiles on the NNV and Limpopo margin (LM) (Figure 2A). Six profiles were extended onshore with 124 land stations from the FCUL pool. The seismic source was composed of an array of 15 airguns, providing a total volume of $6500-\mathrm{in}^{3}$, with a shot interval every $60 \mathrm{~s}$. Method details regarding data processing and constraining a velocity model are available in the supplementary data (see also Lepretre et al., 2017, 2018; Verrier et al., 2017; Schnurle et al., 2018).

\section{RESULTS}

The wide-angle data were modeled using the RAYINVR (Zelt \& Smith 1992; Zelt, 1999) software package applying a layer-stripping approach and iterative damped least-squares travel-time inversion at later stages. Figure 3 presents two examples of the wide-angle results showing that the NNV exhibits a $30 \mathrm{~km}$-thick crust, composed of four crustal layers, with a structure similar to the neighbouring onshore MCP. The propagation velocity in the crust varies from $5.6 \mathrm{~km} / \mathrm{s}$ in the upper crust to $7.3 \mathrm{~km} / \mathrm{s}$ in the lower crust. Whilst the Mohorovicic discontinuity is flat and at a depth of about 33-35 km, except at distal zones, the velocity structure inside the crustal layers presents, in some places, up to $0.5 \mathrm{~km} / \mathrm{s}$ lateral variations (Figure 3). Above the basement, the sedimentary layer is about $5 \mathrm{~km}$ thick, and can be divided in two separated by a strong, probably volcanic reflector (Figure 2B), characterized by seismic velocities ranging from 4.05 to $4.5 \mathrm{~km} / \mathrm{s}$. This reflector was previously interpreted as a magmatic layer of Karoo age (183 Ma) (Salman \& Abdula, 1995). Below it, the refraction data show the presence of 2 to $3 \mathrm{~km}$ of additional strata of probably volcano-sedimentary nature (Figure 3A). To the north, in the MCP, a similar 2-3 km thick sequence of deep reflectors is present below the strong reflector supposed to be related to the Karoo Magmatic event, arguing for a common origin and an onshore-offshore connection. In the center of the NNV, where the basement appears at a shallower depth (4.3-4.8 compared to 5-5.5 km) (Figure 3), reliefs were surveyed in bathymetry and seismic data, during the MOZ3-5 cruise. Carbonate dredges suggest several vertical

This article is protected by copyright. All rights reserved 
motions during the evolution of the margin (Figure 2A).

Figure 4A shows the 1D velocity-depth below seafloor across the MCP at its southern extremity along the MZ7 profile. The 1D-Vz profiles below the seafloor fit perfectly with the velocity field of shields throughout the world (Christensen and Mooney, 1995) indicating that the crust in this region is of continental nature. Figure 4B also shows the resemblance between the MCP and the two conjugate cratons at the time of the Gondwana assemblage: both crustal structures estimated along the Lebombo monocline (35-38 km) (Nguuri et al., 2001; Kwadiba et al., 2003, etc) and below the Grunehogna craton in Antarctica (Hubscher et al., 1996) are similar to the one described by our results. Figure 4C compares the same 1D velocity-depth profiles to the compilation of the «normal » Atlantic oceanic crust (White et al., 1992) and the 1D velocity-depth profiles of some thickened oceanic structures like the Agulhas plateau (Gohl and Uenzelmann-Neben, 2001), the Ontong Java Plateau (Miura et al., 2004), the South Mozambique ridge (Gohl et al., 2011), the Kerguelen plateau (Charvis and Operto, 1999) or the Tuamotu plateau (Patriat et al., 2002). Neither the velocity bounds of these 1D-velocitydepth profiles nor their thickness fit the velocity structure of the MCP.

Figure 5 shows the evolution of the 1D velocity-depth below basement profiles every $10 \mathrm{~km}$ along the N-S MZ7 profile. This evolution demonstrates the genetic link between the MCP and the NNV (Figure 5B). The NNV indeed presents a very similar velocity structure, except for the thickness, implying a southward step-by-step thinning of $10 \mathrm{~km}$ at the base of the continental crust, showing the crucial role of the lower crust (Aslanian et al., 2009). South of Naude ridge, the Moho rises to a depth of $15 \mathrm{~km}$ below sea level and the velocity structure becomes increasingly similar to an oceanic or proto-oceanic type crust (Moulin et al., 2015; Afilhado et al., 2015; Evain et al., 2015).

Our results show the evolution of the $35 \mathrm{~km}$ thick continental crust in the MCP to a thinner continental crust (25-31 km thick) in the NNV. These results are consistent with those proposed by Domingues et al., (2016) in the MCP and Hanyu et al., (2017) for the NNV.

The lateral velocity variations observed in the lower crust of the NNV (Figures $3 \& 5$ ) have already been imaged for other regions such as in the Paleoproterozoic block of the Ukrainian Shield (Thybo et al., 2003; Thybo and Artemieva, 2013), the intracontinental lake Baikal rift (Thybo and Nielsen, 2009) or the intracontinental Parnaïba basin (Tozer et al., 2017). Such variations are interpretated as a presence of mafic and ultramafic mantle materials in the lower or middle continental crust and as

This article is protected by copyright. All rights reserved 
magmatic intrusions (Nunn and Aires, 1988; DeRito et al., 1983; Tozer et al., 2018) or eclogitization of the lower crust (Haxby et al., 1976; Baird et al., 1995). As described for the Arctic Ocean (Shulgin et al., 2018), this part of the Indian Ocean has also experienced several magmatic events at different periods (the Karoo volcanic event, the Turonian trapps event, Eocene, Miocene...), which are observed on the reflection seismic profiles at different levels of the sedimentary layers and may imply the supposed intrusion/transformation of the lower crust.

\section{DISCUSSION}

The presence of $30 \mathrm{~km}$-thick continental crust in the NNV, in continuation of the continental MCP (Domingues et al., 2016), together with the presence of the Beira Continental block in the Zambezi Basin (Mueller et al., 2016) exclude the possibility of an overlap between the Antarctica and Africa plates in that area, as inferred by the most recent kinematic models (Leinweber \& Jokat, 2012; Gaina et al., 2013, 2015; Gibbons et al., 2013; Reeves et al., 2015; Tikku et al., 2002; Torsvik et al., 2008, 2012; Seton et al., 2012; Reeves \& De Wit, 2000; Nguyen et al., 2016; Davis et al., 2016). These results definitely impose a looser fit model confirming kinematic results proposed recently by Thompson et al. (2019).

All these results induce the location of the continental ocean boundary at the limit between the NNV and the SNV, south of the NR (Figure 2A) as inferred by the sea surface vector geomagnetic analysis (Hanyu et al., 2017), and timing at around $135 \mathrm{Ma}$, when the Patagonia plate moved to the west, during the opening of the Austral segment of the South Atlantic ocean.

A $30 \mathrm{~km}$ thick supposed continental crust, similar to the MCP but below more than $1000 \mathrm{~m}$ of the sea level is unexpected. This anomalous topography must be related to the presence of lateral variations in the velocity structure of the crust and the presence of multiple magmatic events recorded in the sedimentary layers. In the Parnaïba basin, Tozer et al. (2017) proposed that the lower part of the continental crust is overloaded by mafic intrusions, inducing subsidence and the formation of the sedimentary basin. Shulgin et al., 2018 equally proposed a deep originating process with emplacement of intrusive mafic bodies at the transition crust/upper mantle. In line with these authors, we propose that several magmatic events (from Karoo to Miocene events) have played a role in the

This article is protected by copyright. All rights reserved 
transformation of the lower crust (intrusion, underplating, metamorphism, etc.), overloading the NNV crust.

The crustal geometry obtained in the NNV evidences the lack of extensive features, arguing against any extensional or a conservational thinning model, like simple shear, pure shear or polyphase models, which exclude exchanges between the lower continental crust and upper mantle (Aslanian \& Moulin, 2012). The small thinning (about $10 \mathrm{~km}$ ) from the MCP to the NNV as well as the presence of a $30 \mathrm{~km}$ continental crust below sea level implies an overloading of the lower part of the crust as proposed in the Parnaïba intracontinental basin (Daly et al., 2018). Our results confirm the complexity of the thinning processes, with several mechanisms such as surface processes, reactivation of inherited structures, melting, thermo-mechanical structure and dyke dynamics providing additional complexity for the tectonic evolution of individual rift systems (Cloetingh et al., 2013; Brune, 2014; Ulvrova et al., 2018; etc...). Other basin forming mechanisms are entailed (Aslanian et al., 2019) and must involve the crucial role of the lower continental crust, which can be affected by mafic intrusions and sometimes flow into the so-called intermediate domain, as was proposed for the South Atlantic Margins (Aslanian et al., 2009; Clerc et al., 2018; Quirk and Rüpke, 2018) and the Provençal Basin (Moulin et al., 2015; Afilhado et al., 2015).

\section{ACKNOWLEDGMENTS}

We warmly thank Captain Thierry Alix, the crews and technicians of the Pourquoi Pas? (IFREMER/GENAVIR). We are indebted to the French Embassies in Mozambique, Guillaume Thieriot and Sophie Jacquel and in South Africa, Jean-Paul Toutain. We thank all the onshore team from IGM/INAMI (especially Dr. Adriano Sênvano) and UeM who make the extension of the profiles on land possible. We acknowledge Francis Malcolm and Schlumberger London for their help in the preparation of the campaign by presenting their seismic data to position the MOZ3-5 profiles. The authors acknowledge the fruitful and constructive English editing advices and corrections by Alison Chalm. And finally, we thank the Editor, Jason Phipps Morgan, Wolfram Geissler and two other anonymous reviewers for their comments, which substantially improved the manuscript.

The oceanographic expedition and study PAMELA-MOZ3/5 is co-funded by TOTAL and IFREMER as part of the PAMELA (Passive Margins Exploration Laboratories) scientific project. 


\section{AUTHORS CONTRIBUTIONS}

The MOZ3/5 Project was led by M. Moulin, D. Aslanian and M. Evain from Ifremer. N. Dias was the coordinator of the MOZ3/5 on-shore experiment and S. Leroy was the coordinator of the Limpopo Margin study. The PAMELA-MOZ35 Team is composed by A. Afilhado ${ }^{4}$, R. Apprioul ${ }^{1}$, A. Bronner ${ }^{1}$, R. Castilla ${ }^{3}$, C. Corela ${ }^{5}$, J. Crozon ${ }^{1}$, C. Davy 1 , E. D’acremont ${ }^{6}$, L. Droz ${ }^{2}$, J.L. Duarte ${ }^{5}$, P. Fernagu ${ }^{1}$, A. Ferrant $^{1}$, M. Fischer ${ }^{7}$, D. Franke ${ }^{8}$, H. Inguane ${ }^{9}$, S. Jorry ${ }^{1}$, G. Jouet ${ }^{1}$, A. Loureiro ${ }^{5}$, P. Le Bouteiller ${ }^{10}$, C. Le Bihan ${ }^{1}$, S. Mahanjane ${ }^{11}$, D. Moocroft ${ }^{12}$, P. Pelleau1 ${ }^{1}$, M. Picot ${ }^{2}$, D. Pierre ${ }^{1}$, M. Pitel ${ }^{1}$, M. Rabineau $^{2}$, C. Rombe ${ }^{13}$, M. Roudaut ${ }^{1}$, A. Senkans ${ }^{6}$ and S. Toucanne ${ }^{1}$.

Comparison of kinematic models was done by J. Thompson during his $\mathrm{PhD}$, financed by the PAMELA Project. Forward Modeling of MZ1 profile was done by A. Leprêtre, M. Evain, P. Schnurle, C. Davy, A. Afilhado, A. Loureiro and F. Verrier. Processing of the deep sounding reflection seismic data was done by P. Schnurle, S. Leroy \& E. D'Acremont and that of the high resolution seismic data by M. Picot, P. De Clarens, L. Droz, P. LeBoutellier. The overall geodynamic interpretation was made by M. Moulin \& D. Aslanian with discussions on seismic and geological with A. Lepretre, P. Schnurle, M. Evain, F. Verrier, J. Thompson and P. De Clarens and on sedimentary process with L. Droz, S. Jorry, G. Jouet, M. Rabineau and S. Toucanne. J. Crozon, M. Roudaut, P. Fernagu, P. Pelleau, R. Apprioual, A. Ferrant, C. LeBihan were the OBS team who operated the seabed instruments during the cruise. SIG and bathymetry processing were done by D. Pierre and M. Pitel. C. Corela, J.L. Duarte, H. Inguane, A. Senkans were active members of the onshore team. Finally A. Bronner, R. Castilla, D. Moocroft, M. Fischer, D. Franke, C. Rombe, S. Mahanjane took part in data acquisition and contributed to the good spirit of the mission.

Data availability statement

The data that support the findings of this study are available from [third party]. Restrictions apply to the availability of these data, which were used under license for this study. Data are available [from the authors / at URL] with the permission of [third party].

\section{REFERENCES CITED}

This article is protected by copyright. All rights reserved 
Afilhado, A., Moulin, M., Klingelhoefer, F., Aslanian, D., Schnurle, P., Nouzé, H., Rabineau M. and Beslier, M. O., 2015, Deep crustal structure across an young passive margin from wide-angle and reflection seismic data (The SARDINIA Experiment) - II. Sardinia's margin, BSGF, ILP Special volume, 186, 331-351, doi:10.2113/gssgfbull.186.4-5.331.

Aslanian, D., Moulin, M., Schnürle, P., Evain, M., Afilhado, A. \& Rabineau, M., Passive margin and continental basin: towards a new paradigm, lere conference of the arabian journal of geosciences (CAJG), 12 -15 November 2018, Hammamet, Tunisia.

Aslanian, D. and Moulin, M., 2012, Paleogeographic consequences of conservational models in the South Atlantic Ocean, In: Mohriak, W.U., Danforth, A., Post, P.J., Brown, D.E., Tari, G.C., Nemcok, M. \& Sinha, S.T. (eds). Conjugate Divergent Margins. Geological Society of London, Special Publications, 369, http://dx.doi.org/10.1144/SP369.5.

Aslanian, D., Moulin, M., Olivet, J.-L., Unternehr, P., Matias, L., Bache, F., Rabineau, M., Nouzé, H., Klingelhoefer, F., Contrucci,. I. and Labails, C., 2009, Brazilian and African passive margins of the Central Segment of the South Atlantic Ocean: kinematic constraints, Tectonophysics, 468, 98-112, doi:10.1016/j.tecto.2008.12.016

Auffret, Y., Pelleau, P., Klingelhoefer, F., Géli, L., Crozon, J., Lin, J.-Y. and Sibuet, J.-C., 2004, MicrOBS: a new generation of ocean bottom seismometer. First Break, 22, 41-47.

Baird, D. J., Knapp, J. H., Steer, D. N., Brown, L. D. and Nelson, K. D., 1995, Upper-mantle reflectivity beneath the Williston Basin, phase-change Moho, and the origin of intracratonic basins, Geology, 23, 431-434

Blaich, O.A., Faleide, J.I., Tsikalas, F., 2011. Crustal breakup and continent-ocean transition at South Atlantic conjugate margins. Journal of Geophysical Research 116, B01402, http://dx.doi.org/10.1029/2010JB007686.

Brune, S., 2014. Evolution of stress and fault patterns in oblique rift systems: 3-D numerical lithospheric-scale experiments from rift to breakup. Geochemistry, Geophysics, Geosystems 15, 3392-3415. http://dx.doi.org/10.1002/2014GC005446.

Brune S., Heine, C., Clift, P.D., Perez-Gussinyé, M., 2017. Rifted margin architecture and crustal rheology: Reviewing Iberia-Newfoundland, Central South Atlantic, and South China Sea, Marine and Petroleum Geology, 79, 257-281.

This article is protected by copyright. All rights reserved 
Charvis, P., and Operto, S., 1999, Structure of the Cretaceous Kerguelen Volcanic Province (southern Indian Ocean) from wide-angle seismic data, J. Geodyn., 28, 51-71, doi:10.1016/S02643707(98)00029-5.

Clerc, C., Ringenbach, J.-C., Jolivet, L. and Ballard, J.F., 2018, Rifted margins : Ductile deformation, boudinage, continentward-dipping normal faults and the role of the weak lower crust, Gondwana Research, 53, 20-40.

Cloetingh, S., Burov, E., Matenco, L., Beekman, F., Roure, F., Ziegler, P.A., 2013, The Moho in extensional tectonic setting: insights from thermo-mechanical models. Tectonophysics, 609, 558-604.

Daly, M. C., Fuck, R. A., Julià, J., Macdonald, D. I. M. and Watts, A. B. 2018. Cratonic Basin Formation: A Case Study of the Parnaíba Basin of Brazil. Geological Society, London, Special Publications, 472, 1-15. https://doi.org/10.1144/SP472.20

Davis, J.K., Lawver, L.A., Norton, I.O. and Gahagan, L.M., 2016, New Somali Basin magnetic anomalies and a plate model for the early Indian Ocean. Gondwana Research, 34, 16-28.

DeRito, R. F., Cozzarelli, F. A. and Hodge, D. S., 1983, Mechanism of subsidence of ancient cratonic rift basins, Tectonophysics, 94, 141-168.

Dingle, R.V. and Scrutton, R.A., 1974, Continental breakup and the development of post-Paleozoic sedimentary basins around southern Africa, Geol. Soc. Am. Bull., 85 , 1467-1474.

Domingues, A., Silveira, G., Ferreira, A.M.G., Chang, S.J., Custodio, S. and Fonseca, J.F.B.D., 2016, Ambient noise tomography of the East African Rift in Mozambique, Geophysical Journal International, 204, 1565-1578, doi: 10.1093/gji/ggv538.

Dove, D., Coakley, B., Hopper, J., Kristoffersen, Y. and HLY0503 Geophysics Team, 2010, Bathymetry, controlled source seismic and gravity observations of the Mendellev ridge; implications for ridge structure, origin, and regional tectonics. Geophysical Journal International, 183, 481-502, doi:10.1111/j.1365-246X.2010.04746.x

Gaina, C., Torsvik, T., Van Hinsbergen, D., Medvedev, S., Werner, S. and Labails, C., 2013, The African Plate: A history of oceanic crust accretion and subduction since the Jurassic. Tectonophysics, 604 Special Issue: SI doi: 10.1016/j.tecto.2013.05.037.

This article is protected by copyright. All rights reserved 
Gaina, C., Van Hinsbergen, D. J.J. and Spakman, W., 2015, Tectonic interactions between India and Arabia since the Jurassic reconstructed from marine geophysics, ophiolite geology, and seismic tomography. Tectonics, 34, 875-906. doi:10.1002/2014TC003780.

Gibbons, A. D., Whittaker, A. D. and Müller, R. D., 2013, The breakup of East Gondwana: Assimilating constraints from Cretaceous ocean basins around India into a best-fit tectonic model, J. Geophys. Res. Solid Earth, 118, 808-822, doi:10.1002/jgrb.50079.

Goodlad, S.W., Martin, A.K. and Hartnady, C.J.H., 1982, Mesozoic magnetic anomalies in the southern Natal Valley. Nature 295, 686-688. http://dx.doi.org/10.1038/295686a0.

Gohl, K. and Uenzelmann-Neben, G., 2001. The crustal role of the Agulhas Plateau, southwest Indian Ocean: evidence from seismic profiling, Geophysical Journal International, 144, 632-646.

Gohl, K., Uenzelmann-Neben, G., Grobys, N., 2011, Growth and dispersal of a southeast african large igneous province. South African Journal of Geology, 114, 379-386, doi:10.2113/gssajg.114.34.379

Green, A.G., 1972, Seafloor spreading in the Mozambique Channel. Nature Phys. Sci. 236, 19-21, 32. Hanyu, T., Nogi, Y. and Fujii, M., 2017, Crustal formation and evolution processes in the Natal Valley and Mozambique Ridge off South Africa, Polar Science 13, 66-81, http://dx.doi.org/10.1016/j.polar.2017.06.002.

Haxby, W. F., Turcotte, D. L. and Bird, J. M., 1976, Thermal and mechanical evolution of the Michigan Basin, Tectonophysics, 36, 57-75

Hubscher, C., Jokat, W. and Miller, H., 1996. Crustal Structure of the Antarctic continental margin in the eastern Weddell Sea. From Storey, B. C., King, E. C. \& Livermore, R. A. (eds), 1996, Weddell Sea Tectonics and Gondwana Break-up, Geological Society Special Publication, 108, 165-174

Kwadiba, M.T.O.G., Wright, C., Kgaswanea, E.M., Simon, R.E. and Nguuri, T.K., 2003. Pn arrivals and lateral variations of Moho geometry beneath the Kaapvaal craton. Lithos, 71, 393-411.

Kukla, P.A., Strozyk, F., Mohriak, W.U., 2018, South Atlantic salt basins - Witnesses of complex passive margin evolution, Gondwana Research 53, 41-57, http://dx.doi.org/10.1016/j.gr.2017.03.012

This article is protected by copyright. All rights reserved 
Kumar, N., 2019, south Atlantic Continental Oceanic Boundary, South Atlantic conjugate Margins Workshop, ION FX Technology's, Rio de Janiero, 11-12 November 2012.

Lafourcade, P., 1984, Etude géologique et géophysique de la marge continentale du sud Mozambique $\left(17^{\circ} \mathrm{S}\right.$ à $\left.28^{\circ} \mathrm{S}\right)$, Thesis, Université Pierre et Marie Curie, Paris VI, France.

Lebedeva-Ivanova, N.N., Zamansky, Y.Y., Langinen, A.E., Sorokin, M.Y., 2006, Seismic profiling across the Mendeleev Rideg at $82^{\circ} \mathrm{N}$ : Evidence of continental crust. Geophysical Journal International, 165, 527-544.

Leinweber, V. and Jokat, W., 2011, Is there continental crust underneath the northern Natal Valley and the Mozambique Coastal Plains? Geophysical Research Letters, 38, L14303.

Leinweber, V. and Jokat, W., 2012, The Jurassic history of the Africa-Antarctica corridor - new constraints from magnetic data on the conjugate continental margins. Tectonophysics 530, $87-$ 101.

Leinweber, V., Klingelhoefer, F., Neben, S., Reichert, C., Aslanian, D., Matias, L., Heyde, I., Schreckenberger, B. and Jokat, W., 2013. The crustal structure of the central Mozambique continental margin - wide-angle seismic, gravity and magnetic study in the Mozambique Channel, Eastern Africa. Tectonophysics, 599, 170-196.

Leprêtre, A., Verrier, F., Evain, M., Schnurle, P., Watremez, L., Aslanian, D., de Clarens, P., Dias, N., Afilhado, A., Leroy, S., d'Acremont, E., Castilla, R. and Moulin, M., 2017. First results on the crustal structure of the Natal Valley from combined wide-angle and reflection seismic data (MOZ3/5 cruise), South Mozambique Margin. EGU 2017 - General Assembly 2017 of the European Geosciences Union, 23-28 April 2017, Vienne.

Lepretre, A., Verrier, F., Schnurle, P., Evain, M., Aslanian, D., Leroy, S., de Clarens, P., Dias, N., Afilhado, A., Gonçalves, S. and Moulin, M., 2018. Insights on the crustal structure of the Natal Valley from combined wide-angle and reflection seismic data (MOZ3/5 cruise), South Mozambique Margin. Seismix2018, 18-22 June 2018, Cracovia

Leroux, E., Aslanian, D., Rabineau, M., Moulin, M., Granjeon, D., Gorini, C. and Droz, L., 2015, Sedimentary markers: a window into deep geodynamic processes, Terra Nova, 27, DOI: 10.1111/ter.12139.

This article is protected by copyright. All rights reserved 
Ludwig, W. J., Nafe, J. E., Simpson, E. S. W. and Sacks, S., 1968, Seismic refraction measurements on the Southeast African Continental Margin, J. Geophys. Res., 73, 3707-3719, doi:10.1029/JB073i012p03707.

Mark, K.M. and Tikku, A.A., 2001, Cretaceous reconstructions of East Antarctica, Africa and Madagascar. Earth and Planetary Science Letters 186, 479-495.

Martin, A.K., Hartnady, C.J.H. and Goodlad, S.W., 1981, A revised fit of South America and South Central Africa, Earth Planet. Sci. Lett., 54 : 295-305.

Miura, S., Nakamura, Y., Shinohara, M., Takahashi, N., Araki, E. and Taira, A., 2004, Seismological structure and implications of collision between the Ontong Java Plateau and Solomon Island Arc from ocean bottom seismometer - airgun data, Tectonophysics, 389, 191-220.

Moulin, M. and Aslanian, D., 2016, PAMELA-MOZ03 cruise report, http://dx.doi.org/10.17600/16001600.

Moulin, M. and Evain, M., 2016, PAMELA-MOZ05 cruise report, http://dx.doi.org/10.17600/16009500.

Moulin, M. Aslanian, D. and Unternehr, P., 2010, A new starting point for the South and Equatorial Atlantic Ocean, Earth Science Reviews, 98, 1-37 doi:10.1016/j.earscirev.2009.08.001.

Moulin, M., Klingelhoefer, F., Afilhado, A., Aslanian, D., Schnurle, P., Nouzé, H., Rabineau, M., Beslier, M.O. and Feld, A., 2015, Deep crustal structure across an young passive margin from wide-angle and reflection seismic data (The SARDINIA Experiment) - I. Gulf of Lion's margin, BSGF, ILP Special volume, 186, 309-330, doi:10.2113/gssgfbull.186.4-5.309.

Mueller, C.O. and Jokat, W., 2019, The initial Gondwana break-up: A synthesis based on new potential field data of the Africa-Antarctica Corridor. Tectonophysics, 750, 301-328. DOI: 10.1016/j.tecto.2018.11.008.

Mueller, C.O., Jokat, W. and Schreckenberger, B., 2016, The crustal structure of Beira High, central Mozambique-Combined investigation of wide-angle seismic and potential field data. Tectonophysics, 683, 233-254.

Nguuri, T.K., Gore, J., James, D.E., Webb, S.J., Wright, C., Zengeni, T.G., Gwavava, O., Snoke, J.A., and Kaapvaal Seismic Group. 2001.Crustal structure beneath southern Africa and its

This article is protected by copyright. All rights reserved 
implications for the formation and evolution of the Kaapvaal and Zimbabwe cratons. Geophysical Research Letters, 28, 2501-2504.

Nguyen, L.C., Hall, S.A., Bird, D.E. and Ball, P.J., 2016, Reconstruction of the East Africa and Antarctica continental margins. J. Geophys. Res. Solid Earth, 121, 4156-4179. doi:10.1002/2015JB012776.

Nunn, J. A., and J. R. Aires, 1988, Gravity anomalies and flexure of the lithosphere at the middle Amazon Basin, Brazil, J. Geophys. Res., 93, 415-428, doi:10.1029/JB093iB01p00415

Patriat, M., Klingelhoefer, F., Aslanian, D., Contrucci, C., Gutscher, M.-A., Talandier, J., Avedik, F., Francheteau, J. and Weigel, W., 2002, Deep crustal structure of the Tuamotu plateau and Tahiti (French Polynesia) based on seismic refraction data, Geophys. R. Letters, 29, 1-4, doi:10.1029/2001GL013913.

Quirk, D. G. and Rüpke, L.H., 2018, Melt-induced buoyancy may explain the elevated rift-rapid sag paradox during breakup of continental plates, Scientific Reports, 8:9985, doi:10.1038/s41598018-27981-2.

Raillard, S., 1990, Les Marges de l'Afrique de l'Est et les Zones de Fracture associées: Chaine Davie et Ride du Mozambique, Thesis, Laboratoire de Géodynamique sous-marine Villefranche-surmer et Département de Géologie Océanique Paris, France.

Reeves, C. and De Wit, M., 2000, Making ends meet in Gondwana: retracing the transforms of the Indian Ocean and reconnecting continental shear zones. Terra Nova 12, 272-280.

Reeves, C., Teasdale, J.P. and Mahanjane, E.S., 2015, Insight into the Eastern Margin of Africa from a new tectonic model of the Indian Ocean. In Nemcok, M., Rybar, S., Sinha, S. T., Hermeston, S. A. \& Ledvényiova, L. (eds), Transform Margins: Development, Controls and Petroleum Systems. Geological Society, London, Special Publications, 431, http://doi.org/10.1144/SP431.12.

Sahabi, M., 1993, Modèle général de l'évolution de l'océan Indien, Thesis, Univ. de Bretagne Occidentale, Brest, France.

Sahabi, M., Aslanian, D. and Olivet, J.-L., 2004, Un nouveau point de départ pour l'histoire de l'Atlantique Central. Compte Rendus de l'Académie des Sciences, 33, 1041-1052.

This article is protected by copyright. All rights reserved 
Salman, G. and Abdula, I., 1995, Development of the Mozambique and Rovuma sedimentary basins, offshore Mozambique. Sedimentary Geology, 96, 7-41.

Sandwell, D. T. and Smith, W. H. F., 2009, Global marine gravity from retracked Geosat and ERS-1 altimetry: Ridge segmentation versus spreading rate, Journal of Geophysical Research, 114 (B1), B01411, doi:10.1029/2008JB006008.

Schnurle, P., Leprêtre, A., Verrier, F., Evain, M., Aslanian, D., Leroy, S., de Clarens, P., Dias, N., Afilhado, A. and Moulin, M., 2018. Crustal structure of the Natal Valley from combined wideangle and reflection seismic data (MOZ3/5 cruise), South Mozambique Margin. Seismix2018, 18-22 June 2018, Cracovia

Seton, M, Müller, R.D., Zahirovic, S., Gaina, C., Torsvik, T., Shepard, G., Talsma, A., Gurnis, M., Turner, M., Maus, S. and Chandler, M., 2012, Global continental and ocean basin reconstructions since $200 \mathrm{Ma}$. Earth-Science Reviews, 113, 212-270.

Shulgin, A., Mjelde, R., Faleide, J.I., Hoy, T., Flueh, E. and Thybo, H., 2018, The crustal structure in the transition zone between the western and eastern Barents Sea. Geophys. J. Int., 214, 315-330.

Thompson, J.O., Moulin, M., Aslanian, D., de Clarens, P., Guillocheau, F., New starting point for the Indian Ocean: Second phase of breakup for Gondwana, Earth-Science Reviews, in press, https://doi.org/10.1016/j.earscirev.2019.01.018

Thybo, H. and Artemieva, I.M., 2013, Moho and magmatic underplating in continental lithosphere. Tectonophysics, 609, 605-619. https://doi.org/10.1016/J.TECTO.2013.05.032.

Thybo, H. \& Nielsen, C. A., 2009. Magma-compensated crustal thinning in continental rift zones. Nature, 457, 873-876, doi:10.1038/nature07688.

Thybo, H., Janik, T., Omelchenko, V.D., Grad, M., Garetsky, R.G., Belinsky, A.A., Karatayev, G.I., Zlotski, G., Knudsen, M.E., Sand, R., et al., 2003, Upper lithospheric seismic velocity structure across the Pripyat Trough and the Ukrainian Shield along the EUROBRIDGE'97 profile. Tectonophysics, 371, 1-4, 41-79. https://doi.org/10.1016/s0040-1951(03)00200-2.

Tikku, A.A., Marks, K.M. and Kovacs, L.C., 2002, An Early Cretaceous extinct spreading center in the northern Natal valley. Tectonophysics, 347, 87-108.

Torsvik, T., Müller, R.D., Van der Voo, R., Steinberger, B. and Gaina, C., 2008, Global plate motion frames: toward a unified model, Reviews of Geophysics, 46, RG3004, 1-44.Torsvik, T., Van der

This article is protected by copyright. All rights reserved 
Voo, R., Preeden, U., Mac Niocaill, C., Steinberger, B., Doubrovine, P.V., Van Hinsbergen, D. J.J., Domeier, M., Gaina, C., Tohver, E., Meert, J.G., McCausland, P.J.A. and Cocks, L.R.M., 2012, Phanerozoic polar wander, palaeogeography and dynamics. Earth-Science Reviews, 114, 328-365.

Tozer, B., Watts, A.B. and Daly, M. C., 2017, Crustal structure, gravity anomalies, and subsidence history of the Parnaíba cratonic basin, Northeast Brazil, J. Geophys. Res. Solid Earth, 122, 5591-5621, doi:10.1002/2017JB014348.

Ulvrova, M. M., Brune, S., \& Williams, S., 2019, Breakup without borders: How continents speed up and slow down during rifting. Geophysical Research Letters, 46, 13381347.https://doi.org/10.1029/2018GL080387

Verrier F., Leprêtre, A., Evain, M., Schnurle, P., Watremez, L., Aslanian, D., De Clarens, P., Dias, N., Afilhado, A., Leroy, S., d'Acremont, E., Castilla, R. \& Moulin, M., 2017. Preliminary results from combined wide-angle and reflection seismic data in the Natal Valley, South Mozambique margin across the Almirante Leite volcanic ridge : MZ2 profile (MOZ3/5 cruise). EGU 2017 General Assembly 2017 of the European Geosciences Union, 23-28 April 2017, Vienne.

Zelt, C.A. and Smith, R.B., 1992, Seismic traveltime inversion for 2-D crustal velocity structure. Geophys. J. Int., 108 (1), 16-34. https://doi.org/10.1111/J.1365-246X.1992.TB00836.X.

Zelt, C.A., 1999, Modeling strategies and model assessment for wide-angle seismic traveltime data. Geophys. J. Int., 139 (1), 183-204. https://doi.org/10.1046/J.1365-246X.1999.00934.X

\section{FIGURE CAPTIONS}

Figure 1. A) Reconstruction of the super-continent Pangea at Permo-trias time (250 Ma) (Olivet \& Aslanian, pers. comm.). Position of the Pangea has been chosen to highlight the parallelism of the two breakups (blue lines) and the meridian circles during the first phase of distension which give birth to the future central Atlantic Ocean and part of the future Indian Ocean. Grey areas correspond to Paleozoic mountains, the red dotted line and hatched red areas to volcanism in relation to distensive events. B) Comparison of several initial reconstructions of the system: Africa / Antarctica / India / Madagascar / Sri Lanka. Each color corresponds to different authors (Sahabi, 1993; Leinweber and Jokat, 2012; Gaina et al., 2013; Reeves et al., 2015; Davis et al., 2016; Nguyen et al., 2016; 
Thompson et al., 2019). Africa is fixed. The figure was modified after Thompson et al., (2019) C) \& D) Consequences for two reconstructions models: C) Sahabi (1993) to the left, D) Leinweber and Jokat (2012) to the right, with the position of the main tectonic plates (black lines) Beira high (dark purple), the Mozambique aseismic ridges (light purple) and North Madagascar aseismic ridge (light red). Austral Africa is fixed. In the Sahabi model (1993), the position of main tectonic plates takes into account the directions of opening, the fit of the magnetic anomalies and homologeous structures like the aseismic Ridges of Mozambique, Madagascar, Astrid, Gunnerus, etc. The Leinweber and Jokat model (2012) mainly focuses on the adjustment between Antarctica and Africa, on the base of fracture zones (Sandwell \& Smith, 2009) and magnetic anomaly studies. NNV signifies North Natal Valley, NR Naude Ridge and MCP Mozambique Coastal Plain.

Figure 2. A) Location map showing the PAMELA-MOZ-3-5 cruises. White circles: OBSs; white triangles: Land stations; Blue lines: seismic acquisition. Black lines: seismic profiles related to the publications of Leinweber et al., 2013 and Mueller \& Jokat, 2016. NNV and SNV for North and South Natal Valley. Magnetic anomalies are identified by Goodlad et al., (1982) and Martin et al., (1981). Black squares indicate the position of the two profiles shown in Figure 3. B) Zoom of the multichannel seismic profile MZ7, highlighting different magmatic episodes on the NNV

Figure 3. Final P-wave velocity models for two of the MOZ3-5 profiles including the model boundaries used during inversion (solid black lines) and iso-velocity contours every $0.20 \mathrm{~km} / \mathrm{s}$ (thin black dotted lines), OBS locations and land seismic stations are indicated by black inverted triangles. Areas constrained by ray-tracing modeling are the shaded areas. The top (acoustic basement) and bottom (Moho) of the substratum are marked in thick black lines. Red vertical lines: crossing point with other MOZ3-5 profiles. A) N/S profile MZ7, with thirty-eight OBS and sixteen land stations (LSS), from the MCP to the north, to the Naude Ridge (NR) to the south. B) E-W profile MZ1, with thirty-eight OBS and sixteen land stations (LSS), from the Lebombo Monocline in the west, to the Mozambique aseismic ridge in the east.

This article is protected by copyright. All rights reserved 
Figure 4. A) 1D-Vz profiles below seafloor extracted every $10 \mathrm{~km}$, in the MCP, from MZ7 (in green) compared to the compilations of Extended Continental crust, Rifted Continental crust and Shields/Platforms (Christensen \& Mooney, 1995); B) Comparison of crustal thickness between the MCP and neighbouring cratons: Kaapval Craton in Africa (Nguuri et al., 2001; Kwadiba et al., 2003) and the Grunehogna Craton in Antarctica (Hubscher et al., 1996); C) the same 1D velocity-depth profiles of the MZ7-MCP profile (in shaded green area) compared to thickened oceanic structures, like the Agulhas plateau (Gohl and Uenzelmann-Neben, 2001), the South Mozambique Ridge (Gohl et al., 2011) the Ontong Java Plateau (Miura et al., 2004), the Kerguelen plateau (Charvis and Operto, 1999) and the Tuamotu plateau (Patriat et al., 2002).

Figure 5. A) P-wave final modeling of the N-S profile MZ7, with the exact position of the extracted Vz-profiles, illustrated on profile MZ7 with the same colors. B) Evolution of the 1-D velocity versus depth below seafloor spaced every $10 \mathrm{~km}$ along the MZ7 profile showing the N/S evolution, marked by a thinning reducing the crustal thickness to a range of 26 to $31 \mathrm{~km}$, and no major change until the NR. This compilation is compared to the one of Extended Continental crust, Rifted Continental crust and Shields/Platforms (Christensen \& Mooney, 1995) and the last domain and also to that of the Atlantic oceanic crust (blue shaded area) (White et al., 1992).

This article is protected by copyright. All rights reserved 

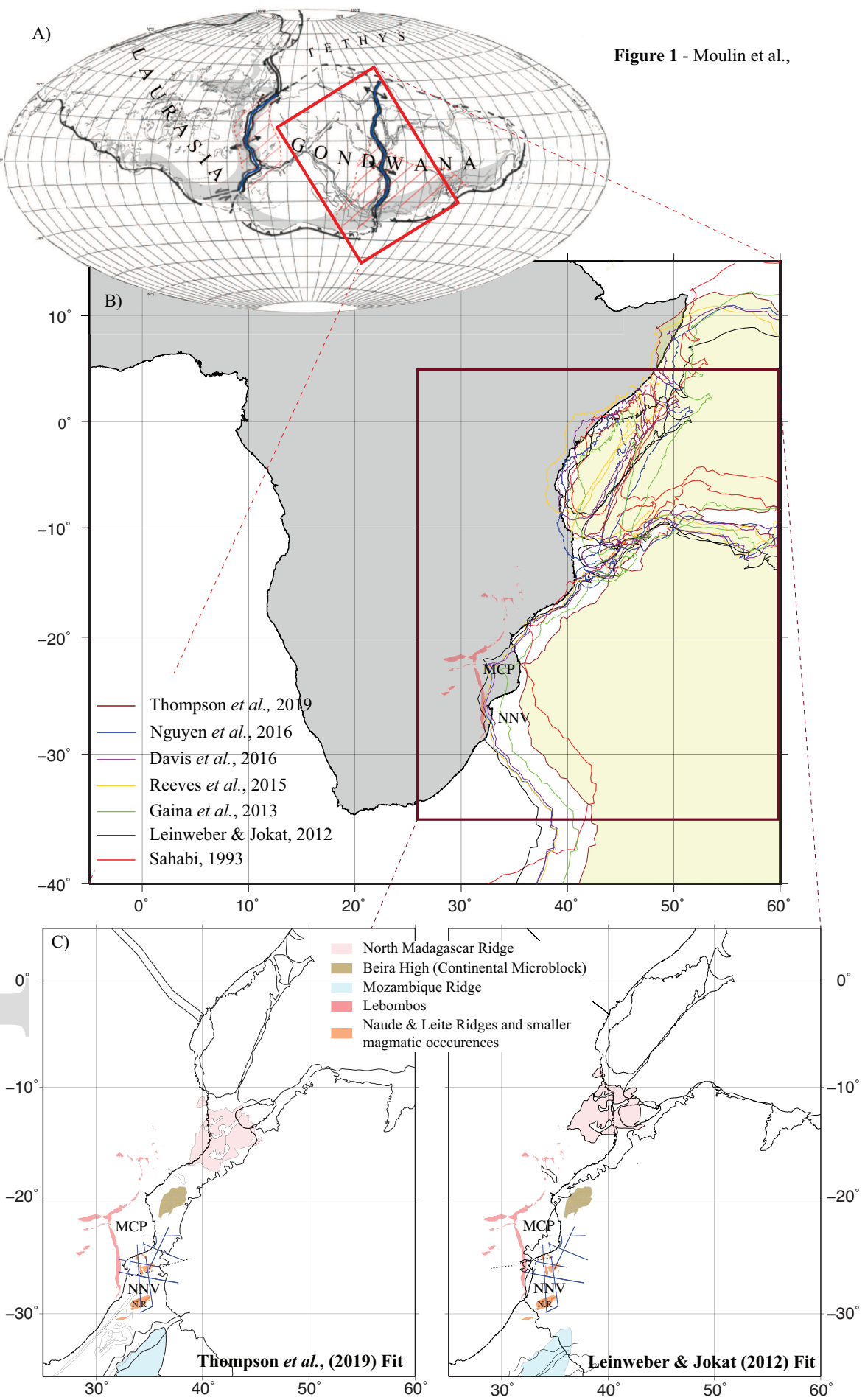

This article is protected by copyright. All rights reserved 


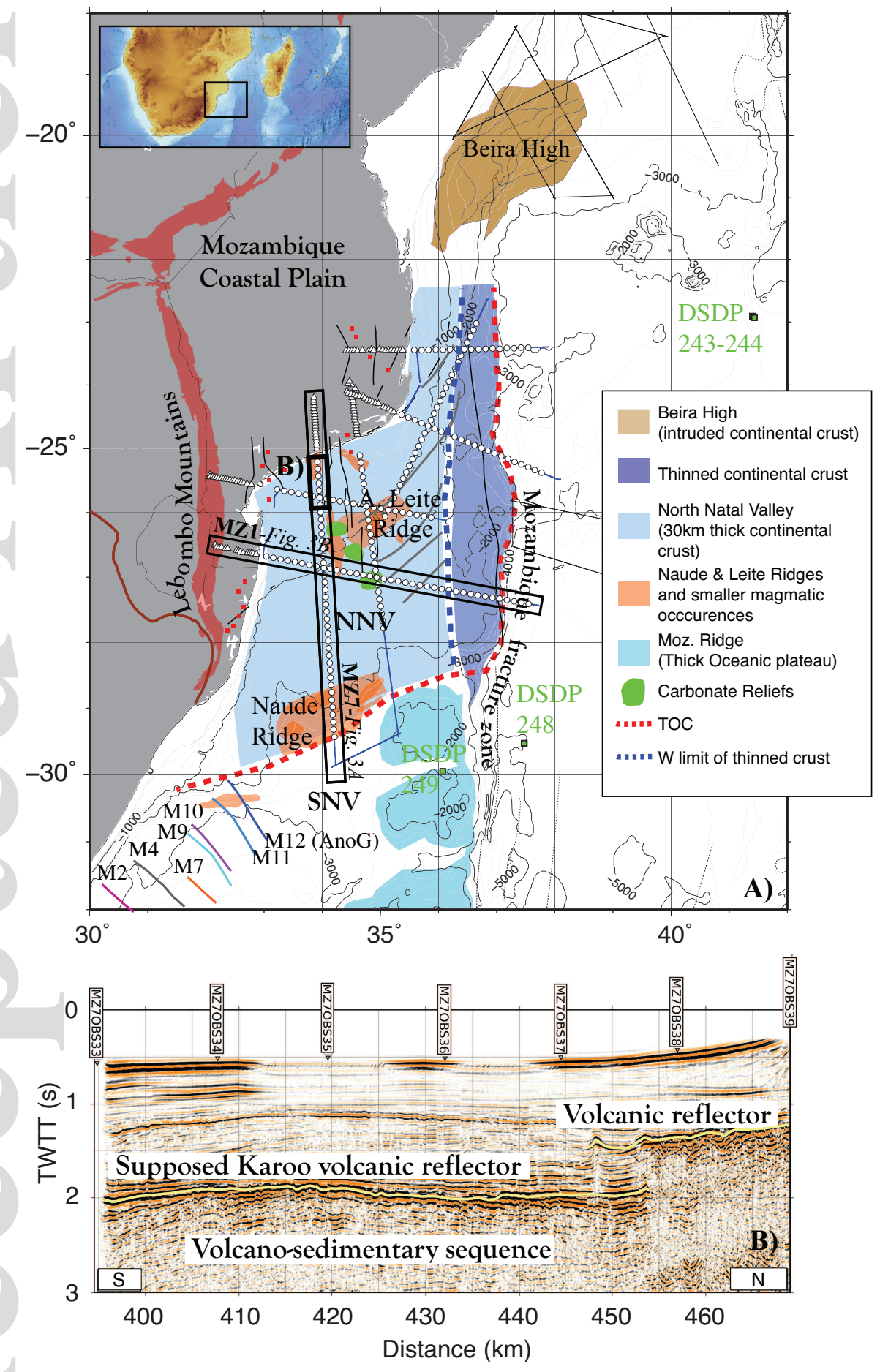

Figure 2 - Moulin et al., 


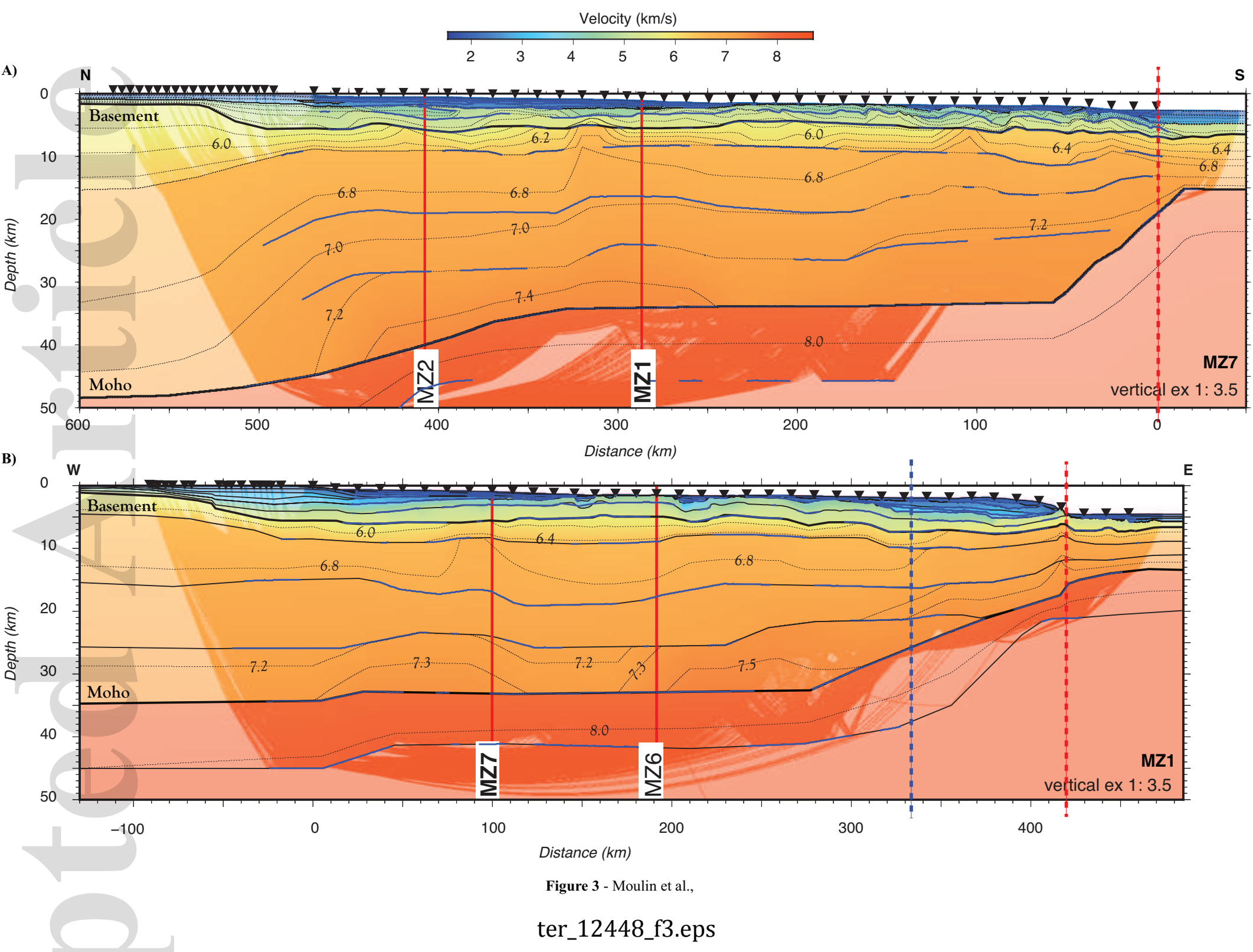

This article is protected by copyright. All rights reserved 
Kaapvaal Grunehogna MCP

Craton Craton This study

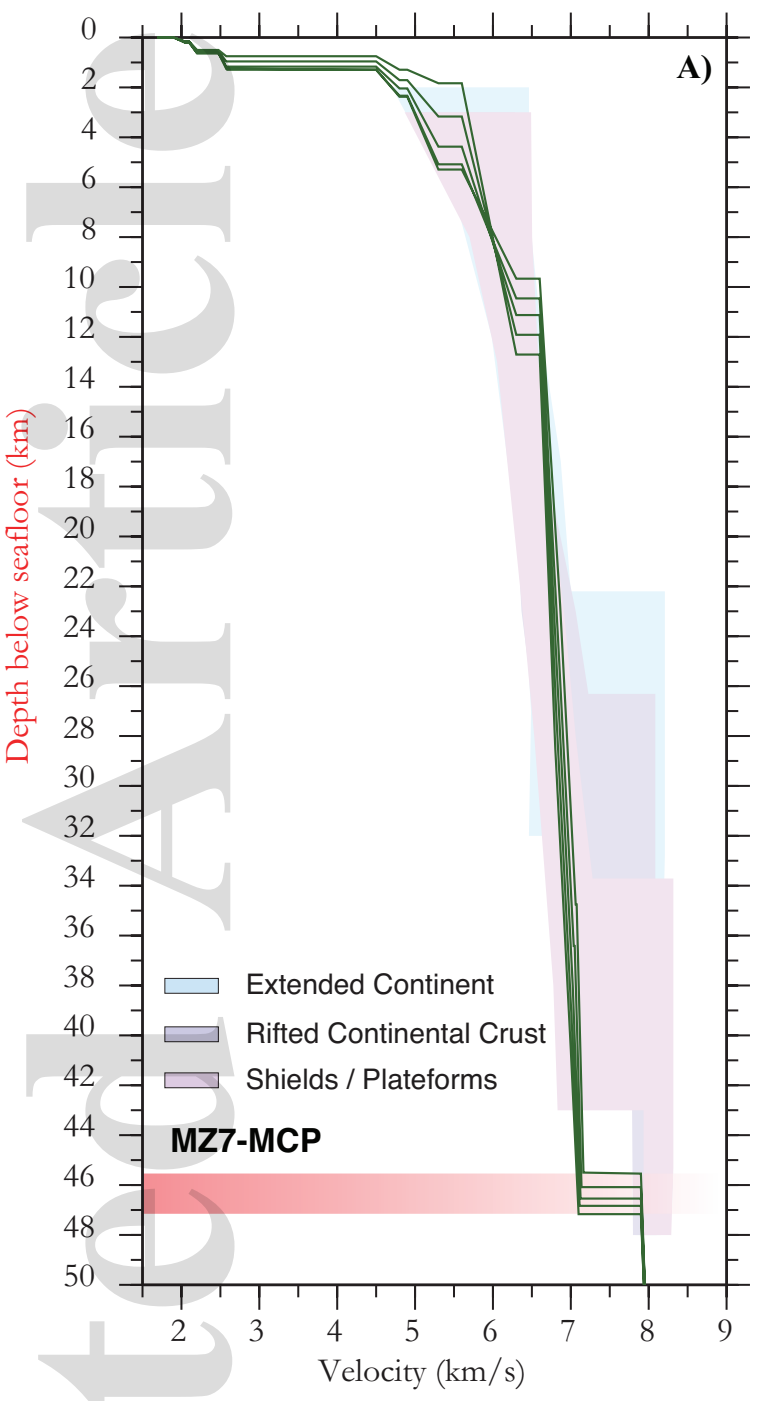

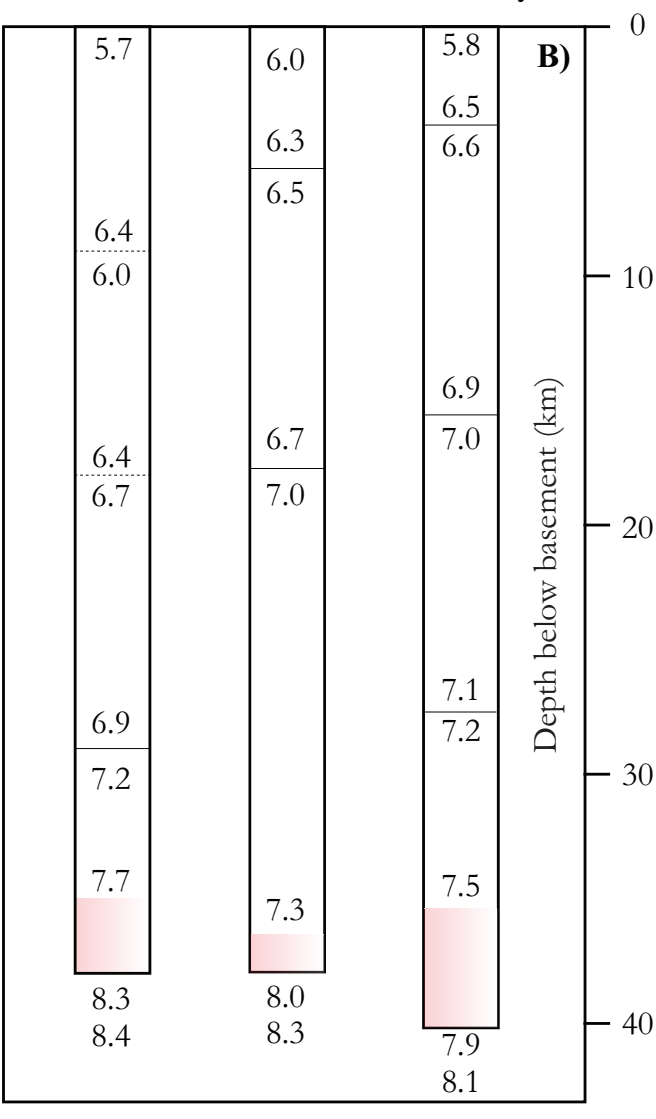

Figure 4 - Moulin et al.,

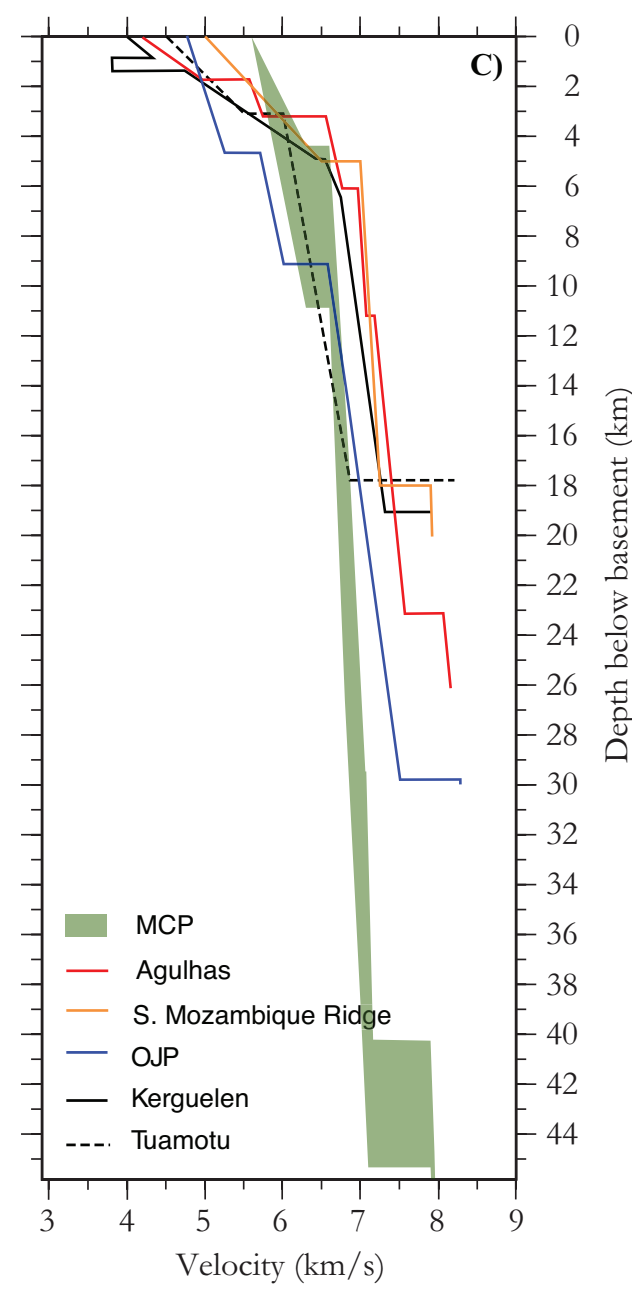

ter_12448_f4.eps 
